\title{
KEKERASAN TERHADAP ANAK YANG DILAKUKAN OLEH ORANG TUA DITINJAU MENURUT UNDANG - UNDANG NOMOR 35 TAHUN 2014 TENTANG PERLINDUNGAN ANAK
}

\author{
Prasetyo Margono, SH, MH
}

\begin{abstract}
Abstrak
Pengkajian mengenai kekerasan terhadap anak yang dilakukan oleh orang tua menurut Undang Undang Nomor 35 Tahun 2014 tentang Perlindungan Anak ini, sebenarnya berawal dari banyaknya kasus kekerasan terhadap anak oleh orang tua yang lepas dari jeratan hukum. Pengangkatan masalah ini terjadi signifikan, apabila dikaitkan dengan faktor - faktor yang menjadi penyebab kekerasan terhadap anak, dimana kekerasan terhadap anak secara garis besar disebabkan tidak hanya dari factor salah didik dari para orang tua. Pengkajian ini bertujuan untuk mengetahui apa yang menjadi penyebab terjadinya kekerasan terhadap anak oleh orang tua yang sering terjadi didalam suatu masyarakat, serta untuk mengetahui bagaimana cara - cara untuk mengurangi atau mencegah terjadinya kekerasan terhadap anak oleh orang tua. Dari pokok hasil kajian dapat disimpulkan bahwa factor - factor yang menjadi penyebab kekerasan terhadap anak oleh orang tua, pada umumnya dikarenakan factor human eror (kelalaian manusia / orang tua dan anak), factor ekonomi, factor tradisi, serta kurangnya peran serta masyarakat dalam mencegah terjadinya kekerasan terhadap anak yang dilakukan oleh orang tua.
\end{abstract}

\section{Kata Kunci: Kekerasan terhadap anak, ditinjau dari undang-undang perlindungan anak}

\section{A. PENDAhuluan}

Negara Republik Indonesia adalah negara yang menganut sistim negara hukum. Hal ini sebagaimana disebutkan dalam penjelasan Undang - Undang Dasar 1945 sebelum diamandemen ( selanjutnya disingkat UUD 1945 ) yang menyatakan bahwa Indonesia ialah negara yang berdasarkan atas hukum (rechtstaat), tidak berdasar atas kekuasaan belaka (machstaat).

Sebagaimana negara hukum, maka konsekuensinya adalah harus menjunjung tinggi hukum yang berlaku. Semua perbuatan yang dilakukan oleh negara yakni perbuatan pemerintah dan lembaga - lembaga negara lainnya harus berdasarkan hukum atau dapat dipertanggung jawabkan secara hukum.

Pengertian negara hukum menurut Padmo Wahjono sebagaimana yang dikutip oleh Gatot Supramono dijelaskan bahwa negara hukum yang dimaksudkan dalam UUD 1945 tersebut mengandung arti yang luas, yang meliputi :

- Negara hukum dalam arti formal,

\section{- Negara hukum dalam arti material ${ }^{77}$}

Negara hukum dalam arti formal maksudnya bahwa negara melindungi segenap bangsa Indonesia dan seluruh tumpah darah Indonesia. Disini negara mempunyai fungsi sebagai pelindung setiap warga negara Indonesia, jangan sampai terjadi pelanggaran serta menindak pelaku pelanggar hukum, sedangkan negara dalam arti material mempunyai maksud bahwa negara harus memajukan kesejahteraan umum dan mencerdaskan kehidupan bangsa, dan menjalankan roda Pemerintahan, pembangunan dan hal - hal lain yang yang dapat bermanfaat bagi bangsa dan negara. Kedudukan anak dalam kehidupan bangsa dan negara adalah sangat penting dan menentukan. Karena anak merupakan generasi penerus bangsa pada masa yang akan datang, maju tidaknya suatu negara nantinya tergantung

${ }^{77}$ Gatot Supramono, Hukum Pembuktian di Pengadilan Agama, Alumni, Bandung, 1993.

h. 1 . 
pada generasi muda suatu negara tersebut. Sebagai generasi penerus bangsa, setiap anak agar kelak mampu memikul tanggung jawab tersebut, maka ia perlu mendapatkan kesempatan yang seluas - luasnya untuk tumbuh dan berkembang secara optimal, baik secara fisik, mental, maupun sosial, serta mempunyai akhlak yang mulia.

Perlu diadakan upaya perlindungan serta untuk mewujudkan kesejahteraan anak dengan memberikan jaminan terhadap pemenuhan hak -haknya serta adanya perlakuan tanpa diskriminasi dari siapapun.

Dalam rangka untuk membangun bangsa dan bernegara, diperlukan generasi penerus yang cerdas, tanggung jawab, dan berakhlak mulia. Untuk itu, diperlukan perlindungan, pendidikan, serta pembinaan yang baik dan terarah terhadap anak.

Dalam Pasal 9 Ayat (1) Undang Undang Nomor 35 Tahun 2014 disebutkan "setiap anak berhak

memperoleh pendidikan dan pengajaran dalam rangka pengembangan pribadinya dan tingkat kecerdasannya sesuai dengan minat dan bakat". Sebagai pertanggung jawaban orang tua, keluarga, masyarakat, pemerintah dan negara merupakan rangkaian kegiatan yang dilakukan secara terus menerus demi terlindunginya hak - hak anak. Rangkaian kegiatan tersebut harus berkelanjutan dan terarah guna menjamin pertumbuhan dan perkembangan anak, baik fisik, mental, spiritual, maupun sosial. Tindakan ini dimaksudkan untuk mewujudkan kehidupan terbaik bagi anak, yang diharapkan sebagai penerus bangsa yang potensial, tangguh, memiliki nasionalisme yang dijiwai oleh akhlak mulia dan nilai pancasila, serta berkemauan keras menjaga persatuan dan kesatuan bangsa dan negara.

Dari uraian latar belakang diatas, sangat menarik untuk mengkaji dan mengadakan penilaian dengan berjudul Kekerasan Terhadap Anak Yang Dilakukan Oleh Orang Tua Ditinjau Menurut Undang - Undang Nomor 35 Tahun 2014 Tentang Perlindungan Anak.

\section{B. Metode penelitian}

Masalah metode penelitian dalam setiap penulisan karya ilmiah termasuk dalam pembuatan skripsi memegang peranan penting, sebab penelitian merupakan suatu salah satu sarana utama dalam pengembangan ilmu pengetahuan teknologi. Tidaklah berlebihan, apabila burhan bugin menyatakan bahwa "penelitian dan ilmu pengetahuan bagaikan dua sisi dari satu mata uang. ${ }^{78}$ Dalam hal ini kedua sisi tersebut sangat berkaitan Penelitian dan ilmu pengetahuan tidak mungkin dapat dipisahkan satu sama lainnya, atau dengan kata lain penelitian akan berkurang maknanya, kecuali dipergunakan untuk kebutuan ilmu pengetahuan, Sedangkan ilmu pengetahuan akan menjadi mandul bahkan akan berhenti (mandeg) sama sekali apabila tanpa disertai dengan penelitian.

"hal ini disebabkan, oleh karena penelitian bertujuan untuk menggali atau mengungkap kebenaran secara sistematis, metodologis, dan konsisten. ${ }^{79}$ Melalui proses penelitian diadakan analisis dan konstruksi terhadap data yang telah dikumpulkan dan diolah. Menurut Sutrisno Hadi yang memberikan batasan pengertian penelitian adalah "usaha untuk menemukan, mengembangkan dan menguji kebenaran suatu pengetahuan, dimana usaha itu dilakukan dengan menggunakan metode ilmiah. ${ }^{80}$ Sedangkan menurut Bambang Waluyo, memberikan pengertian penelitian sebagai suatu kegiatan terencana, dilakukan dengan metode ilmiah bertujuan untuk mendapatkan data baru guna membuktikan kebenaran atau ketidakbenaran dari gejala atau hipotesis yang ada. ${ }^{81}$ Dalam penulisan skripsi ini titik pangkal metode yang dipergunakan adalah disiplin ilmu hukum. Oleh roni haniyijo soemitro dinyatakan bahwa, "pada dasarnya penelitian hukum dapat dibedakan menjadi penelitian

78 Burhan Bugin, Metodologi Penelitian Sosial, Format - Format Kuantitatif Dan Kualitatif, Airlangga University Press, Surabaya 2001. h. 3.

79 Soerjono Soekamto Dan Sri Mamuji, Penelitian Hukum Normatif, Raja Grafindo Persada, Jakarta, 1995. h. 4

${ }^{80}$ Sutrisno Hadi, Metodologi Research, Fakultas

Psikologi UGM, Yogyakarta, 1981. h. 3

${ }^{81}$ Waluyo, Penelitian Hukum Dalam Praktek, Sinar

Grafika, Jakarta, 1996. h. 2 
hukum normative, dan penelitian hukum sosiologis. ${ }^{82}$

\section{Tipe Penelitian}

Tipe penelitian hukum yang dilakukan adalah yuridis normatif (hukum normatif). Metode penelitian hukum normatif adalah suatu prosedur penelitian ilmiah untuk menemukan kebenaran berdasarkan logika keilmuan hukum dari sisi normatifnya. ${ }^{83}$ Oleh karena itu, penelitian hukum ini difokuskan untuk mengkaji penelitian hukum tentang kaidah kaidah atau norma - norma dalam hukum positif, yakni norma hukum yang terkait dengan hak atas perlindungan anak.

\section{Hasil penelitian}

Masalah kekerasan terhadap anak, merupakan masalah yang cukup rumit dan sangat beragam, mulai dari masalah kekerasan yang ringan sampai pada masalah kekerasan yang berat, misalnya eksploitasi anak, kekerasan fisik, pelecehan seksual, penelantaran, sampai pada masalah perdagangan anak, yang semua itu dapat mempengaruhi terhadap jiwa dan mental sianak yang masih labil.

Pada umumnya, masalah kekerasan terhadap anak sebagaimana yang telah diuraikan diatas, merupakan masalah yang sering kita jumpai dan kita dengar dimedia massa, baik cetak maupun elektronik.

Dipandang dari keseluruhan masalah kekerasan terhadap anak yang diuraikan diatas, pemerintah selaku pihak yang memiliki kewajiban guna mengatasi masalah kekerasan terhadap anak yang dapat mengganggu keselamatan dalam kehidupan sianak, baik secara fisik maupun mental, akan sangat berpengaruh terhadap sianak.

Seharusnya pemerintah berusaha lebih keras dalam berupaya untuk mengatasi semua masalah yang ada, dengan menciptakan beberapa ketentuan dan peraturan perundang - undangan yang bisa

${ }^{82}$ Roni Hanitijo Soemitro,
Hukum Dan Juru Metri,
$\begin{aligned} & \text { 1990. h. } 9 \\ & \text { Ghalia Indonesia, Jakarta, }\end{aligned}$
Jhony Ibrahim, $\underline{\text { Teori Metode }}$ Penelitian Hukum Normatif, Banyumedia Publishing, Malang, 2005. h. 47 melindungi hak - hak anak di Indonesia dari kekerasan.

Pelanggaran terhadap hak - hak anak oleh orang tua, merupakan hal yang sering terjadi didalam rumah tangga, terutama yang berada diwilayah pedesaan, terutama desa desa yang masih terpencil, jauh dari perkotaan, serta yang penduduknya belum banyak mengenal hukum, dan kebanyakan penduduknya masih mempertahankan tradisi lama.

Letak tanggung jawab terhadap diri sianak berada dipundak orang tua, termasuk pendidikan dan pengasuh anak, tanggung jawab tersebut memang menjadi pekerjaan yang tidak gampang bagi orang tua, bahkan tugas dan tanggung jawab tersebut semakin terasa berat, kalau anak - anak mereka tidak patuh pada pemerintah dan bimbingan dari orang tua.

Menurut Undang - Undang Nomor 23 Tahun 2002 tentang perlindungan anak adalah segala kegiatan untuk menjamin dan melindungi anak dan hak-haknya agar tetap hidup, tumbuh, berkembang, dan berpartisipasi secara optimal sesuai dengan harkat dan martabat kemanusiaan, serta mendapat perlindungan dari kekerasan dan diskriminasi. ${ }^{84}$ Banyak peristiwa kekerasan yang terjadi pada anak disebabkan karena kurang sabar atau tidak telatennya orang tua dalam mengasuh anak mereka, sehingga mereka mudah sekali terpancing emosinya yang kemudian disertai dengan tindakan kekerasan (penganiayaan). Sikap dan perilaku anak mudah sekali terpengaruh oleh keadaan disekitar mereka, karena pola piker dan kejiwaan mereka masih labil dan oleh karena itu, diperlukan peran serta masyarakat dalam membimbing dan mengarahkan kepada hal hal yang bersifat positif. Pada pasal 304 KUHP disebutkan : "barang siapa dengan sengaja menyebabkan atau membiarkan orang dalam kesengsaraan, sedang ia wajib member kehidupan, perawatan atau pemeliharaan pada orang itu karena hukum yang berlaku atasnya atau karena menurut perjanjian, dihukum

\footnotetext{
84 Undang-undang Nomor 23 Tahun 2002 Tentang Perlindungan Anak (Bandung: Citra Umbara,2003). h. 35.
} 
penjara selama - lamanya dua tahun delapan bulan.

Setiap tindak kekerasan atau penganiayaan pasti mempunyai akibat, baik akibat bagi korban, maupun akibat bagi pelaku. Begitu pula kasus kekerasan terhadap anak oleh orang tua juga mempunyai akibat, yaitu akibat bagi sianak selaku korban, dan akibat bagi orang tua sebagai pelaku tindak kekerasan.

Dipandang dari keseluruhan masalah kekerasan terhadap anak yang ada, sedikit sekali yang dapat dijerat oleh hukum. Oleh karena itu, pemerintah selaku pihak yang memiliki kewajiban utama guna mengatasi masalah yang dapat menganggu keselamatan jiwa anak dari tindak kekerasan.

Dalam Undang - Undang Nomor 35 Tahun 2014 ini, meletakkan kewajiban memberikan perlindungan kepada anak berdasarkan pancasila dan berlandaskan Undang - Undang Dasar Negara Republik Indonesia Tahun 1945. Negara, pemerintah, masyarakat, keluarga dan orang tua bertanggung jawab terhadap penyelenggaran perlindungan anak. Kitab undang - undang hukum pidana (KUHP) sebagai salah satu sumber hukum positif Indonesia, juga mengatur mengenai ketetapan kekerasan terhadap anak, perlindungan terhadap anak secara langsung maupun pengaturan kekerasan secara umum.

Penganiayaan dalam pasal - pasal tersebut, akan memdapat pemberantasan hukuman apabila dilakukan oleh orang tua kepada anak mereka sendiri, atau anak kepada orang tuanya, yaitu akan ditambah hukumannya sepertiga dari ketentuan yang ada, sesuai dengan Pasal 356 butir (1e).

Undang - Undang Nomor 35 Tahun 2014 tentang perlindungan anak, dibentuk untuk melaksanakan kewajiban yang diatur dalam undang - undang dasar 1945, menugaskan kepada lembaga - lembaga tinggi negara dan seluruh aparatur pemerintah untuk menghormati, menegakkan dan menyebarluaskan pemahaman mengenai hak hak anak kepada seluruh masyarakat, serta segera meratifikasi berbagai instrument perserikatan bangsa - bangsa tentang hak asasi manusia, sepanjang tidak bertentangan dengan pancasila dan Undang - Undang Dasar 1945.
Dalam Undang - Undang Nomor 35 Tahun 2014 ini, pengaturan mengenai perlindungan anak ditentukan dengan berpedoman pada Deklarasi perlindungan anak perserikatan bangsa - bangsa, konvensi perserikatan bangsa - bangsa tentang penghapusan segala bentuk diskriminasi terhadap wanita, konvensi perserikatan bangsa - bangsa tentang hak hak anak, dan berbagai instrument internasional lain yang mengatur mengenai hak asasi manusia.

Selain hak - hak diatas, juga diatur hak untuk memperoleh pendidikan dan pengajaran, hak untuk mencari, menerima, memberikan informasi, anak juga berhak untuk beristirahat, bergaul dengan anak yang sebaya, bermain, berkreasi, dan berekreasi, serta berhak memperoleh pelayanan kesehatan, dan juga jaminan sosial secara layak.

Dalam hal anak cacat fisik dan atau mental, berhak untuk memperoleh perawatan, pendidikan, pelatihan, dan bantuan khusus dengan biaya negara untuk menjamin kehidupannya, sesuai dengan martabat kemanusiaan, meningkatkan rasa percaya diri, dan kemampuan berpartisipasi dalam kehidupan bermasyarakat, berbangsa dan bernegara.

Dengan demikian, kebijakan dan program aksi perlindungan anak berperan sebagai piranti kelembagaan dalam melindungi anak dari tindakan kekerasan.

Walaupun Undang - Undang Nomor 35 Tahun 2014, telah mencantumkan dan mengatur tentang hak - hak anak, tetapi dalam kewajiban dan tanggung jawab terhadap orang tua, keluarga, masyarakat, pemerintah dan negara untuk memberikan perlindungan kepada anak masih memerlukan suatu peraturan dan ketentuan mengenai perlindungan anak, sehingga terdapat landasan yuridis bagi pelaksanaan kewajiban dan tanggung jawab tersebut.

\section{PENUTUP}

Berdasarkan dari apa yang menjadi topik pembahasan skripsi ini, dapat ditarik kesimpulan sebagai berikut.

Pengaturan dan ketentuan mengenai kekerasan terhadap anak menurut hukum positif Indonesia Dalam pengaturan hukum positif 
Indonesia, secara tugas melarang terjadinya kekerasan terhadap anak, serta dijamin kesejahteraannya. Undang - Undang Dasar 1945 sebagai dasar dari peraturan perundang undangan, menetapkam perlindungan terhadap hak - hak anak yang terdapat dalam pasal 28B ayat (2), dan pada pasal 34. Kemudian ketentuan yang terdapat dalam KUHP pada Bab XX tentang penganiayaan pasal 351 sampai dengan pasal 358, dalam pasal - pasal tersebut dijelaskan mengenai tindak kekerasan (penganiayaan) secara umum, termasuk juga kekerasan terhadap anak. Undang - Undang Nomor 35 Tahun 2014 tentang perlindungan anak, juga mengatur mengenai masalah kekerasan terhadap anak. Dalam Undang Undang Nomor 35 Tahun 2014 tentang perlindungan anak secara umum, mulai dari hak - hak anak dan kewajiban anak, perlindungan terhadap hak - hak anak, keawajiban orang tua, keluarga, masyarakat, pemerintah, dan negara dalam penyelenggaraan perlindungan terhadap anak, sampai pada ketentuan pidana bagi pelaku tindak kekerasan terhadap anak. Aspek aspek hukum kekerasan terhadap anak oleh orang tua ditinjau menurut Undang - Undang Nomor 35 Tahun 2014 Meskipun dalam Undang - Undang Nomor 35 Tahun 2014 tentang perlindungan anak telah mencantumkan tentang hak anak yang terdapat dalam pasal 4 sampai pasal 19, tetapi dalam pelaksanaan kewajiban dan tanggung jawab orang tua, keluarga, masyarakat, pemerintah, dan negara untuk memberikan perlindungan pada anak masih memerlukan suatu undang undang mengenai perlindungan anak sebagai landasan yuridis bagi pelaksanaan kewajiban dan tanggung jawab tersebut.

\section{E. DAFTAR PUSTAKA}

Bambang Waluyo, Penelitian Hukum Dalam Praktek, Sinar Grafika, Jakarta, 1996.

Burhan Bugin, Metode Penelitian Social, Format - Format Kuantitatif Dan Kualitatif, Airlangga University Press, Surabaya, 2001.

Gatot Pramono, Hukum Pembuktian Di Pengadilan Agama, Alumni Bandung, 1993
Harahap, M. Yahya, Pembahasan Masalah Dan Penerapan KUHAP, Pustaka Kartini, Jakarta, 1985.

Hilman Hardikusuma, Metode Pembuatan Kertas Kerja Atau Skripsi, Mandar Maju, Bandung, 1995

Lamintang, P.A.F, KUHAP Dengan Pembahasan Secara Yuridis Menurut Yurisprudensi Dan Ilmu Hukum Pidana, Sinar Baru, Bandung, 1985.

Notosoedirjo, Moeljono dan Latipun, Kesehatan Mental, Universitas Muhammadiyah Malang, Malang, 2005.

R. Soesilo, Kitab Undang - Undang Hukum Pidana (KUHP), Politeia, Bogor, 1988.

Roni Hanitijo Soemitro, Metodologi Penelitian Hukum Dan Jurimetri, Ghalia Indonesia, Jakarta, 1990.

Soerjono Soekanto Dan Sri Mamuji, Penelitian Hukum Normatif, Raja Grafido Persada, Jakarta, 1995.

Sudarto, Hukum dan Hukum Pidana, Alumni, Bandung. 1997.

Sutrisno Hadi, Metodologi Research, Fakultas UGM, Yogyakarta, 1981.

Tahir Hadari Djewani, Pokok - Pokok Pikiran Dalam KUHP, Alumni Bandung, 1981.

Waluyadi, Hukum Perlindungan Anak, CV. Mandar Maju, Bandung, 2009.

$\begin{array}{lrr}\ldots \ldots . . . ., \quad \text { Undang } & - & \text { Undang } \\ \text { Perlindungan Anak } & \text { 2014, }\end{array}$
www.hukumonline.com. Undang - Undang Republik Indonesia Nomor 23 Tahun 2002 Tentang Perlindungan Anak, Citra Umbara, Bandung, 2003. 